\title{
INTRA-ANNUAL VARIATION IN FISH COMMUNITIES AND HABITAT ASSOCIATIONS IN A CHIHUAHUA DESERT REACH OF THE RIO GRANDE/RIO BRAVO DEL NORTE
}

\author{
Thomas C. Heard ${ }^{1}$, Joshuah S. Perkin ${ }^{1,2}$, and Timothy H. Bonner ${ }^{1,3}$
}

\begin{abstract}
Anthropogenic alterations to lotic systems are often implicated in global declines among stream-dwelling fishes. A primary step toward mediating fish declines is improving our understanding of species-environment relationships; unfortunately, such information is limited. The goal of this study was to assess relationships between fish communities and environmental variables in a relatively intact portion of the Rio Grande/Rio Bravo del Norte in the southwestern United States and northern Mexico. We quantified the relationship between riverine habitats and local fish communities at 7 sites in the Big Bend reach of the Rio Grande/Rio Bravo del Norte during 2006. Monthly collections yielded 10,565 individuals representing 20 species, including 6 species listed as threatened or otherwise at risk. Species richness varied among sites (range 13-19) as did diversity (1 - D: 0.49-0.72) and density (16-45 fish $\cdot 100 \mathrm{~m}^{-2}$ ). Fish community composition indicated spatial and temporal variations, but habitat characteristics indicated more variation among sampling sites than among months. Spatial variation in community structure correlated with site-specific habitat characteristics, and most threatened or at risk species were associated with run or riffle geomorphic units containing higher current velocities and gravel to cobble substrates. Temporal variation in community structure correlated with fall monsoonal flooding, during which composition of dominant species shifted from the habitat generalist red shiner (Cyprinella lutrensis) to the imperiled, regionally endemic Tamaulipas shiner (Notropis braytoni). Results from this study suggest that large flood pulses and maintenance of habitat heterogeneity are necessary for the persistence of both declining and intact local fish communities in the Rio Grande/Rio Bravo del Norte.
\end{abstract}

RESUMEN.-Las alteraciones antropogénicas a los sistemas lóticos están con frecuencia implicadas en las declinaciones globales entre peces de arroyos. Un paso primordial para mediar la disminución de los peces, es mejorar nuestro entendimiento de las relaciones entre las especies y su ambiente; desafortunadamente, dicha información es limitada. El objetivo de este estudio fue evaluar las relaciones entre las comunidades de peces y las variables ambientales en una parte relativamente intacta del Río Grande/Río Bravo del Norte al suroeste de los Estados Unidos y al norte de México. Cuantificamos la relación entre los hábitats ribereños y las comunidades locales de peces en 7 sitios del tramo Big Bend del Río Grande/Río Bravo del Norte durante el 2006. Las colecciones mensuales aportaron 10,565 individuos representando a 20 especies, incluyendo a 6 especies listadas como amenazadas en riesgo. La riqueza de especies varió entre sitios (con un rango de 13-19) al igual que la diversidad ( $1-\mathrm{D}: 0.49-0.72)$ y la densidad $\left(16-45\right.$ peces $\cdot 100 \mathrm{~m}^{-2}$ ). La composición de la comunidad de peces indicó variaciones espaciales y temporales, pero las características del hábitat indicaron más variaciones entre los sitios de muestreo que entre los meses. La variación espacial en la estructura de la comunidad estuvo correlacionada con las características del hábitat específicas al sitio, y la mayoría de las especies amenazadas o en riesgo estuvieron asociadas con unidades geomórficas de correderas o rápidos con corrientes de velocidades mayores y sustratos de grava o guijón. La variación temporal en la estructura de la comunidad estuvo correlacionada con las inundaciones otoñales del monzón, durante las cuales la especie dominante cambió de la generalista carpita rojiazul (Cyprinella lutrensis), a la especie en peligro y regionalmente endémica sardinita pechona de Tamaulipas (Notropis braytoni). Los resultados de este estudio sugieren que los pulsos de inundación grandes y el mantenimiento de la heterogeneidad del hábitat son necesarios para la sobrevivencia de las comunidades locales de peces, tanto en declinación como las intactas, en el río Bravo del Norte.

Deterministic fitness, stochasticity, speciation, and dispersal regulate biotic communities within streams at local, regional, and continental scales (Vellend 2010). Anthropogenic modifications to streams often disrupt these regulatory processes and contribute to the current state of crisis facing freshwater biodiversity
(Dudgeon et al. 2006). Reductions in the abundance and distribution of freshwater fishes are particularly notable (Helfman 2007). In North America, nearly $40 \%$ of freshwater and diadromous fishes are imperiled (i.e., at risk of population decline or extinction; Jelks et al. 2008); in the southwestern USA, $>50 \%$ of stream

${ }_{2}^{1}$ Department of Biology/Aquatic Station, Texas State University-San Marcos, 601 University Drive, San Marcos, TX 78666.

${ }^{2}$ Present address: Division of Biology, Kansas State University, 116 Ackert Hall, Manhattan, KS 66506.

3Corresponding author. E-mail: tbonner@txstate.edu 
fishes are considered extirpated (Hughes et al. 2005); and in the Rio Grande/Rio Bravo del Norte Basin (hereafter, Rio Grande), $43 \%$ of native species are missing from all or portions of their historical range (Calamusso et al. 2005). Declines in abundance and distribution of native fishes are often associated with human-mediated changes (e.g., dam construction, water diversion) to naturally occurring fluvial conditions (Holden 1979, Winston et al. 1991, Hoagstrom et al. 2008), but specific mechanisms and causal factors of species declines remain largely unknown. Conservation approaches in which entire communities rather than specific species are considered hold the greatest potential for identifying and subsequently mediating factors contributing to the decline and extirpation of multiple organisms (Scott and Helfman 2001, Bunn and Arthington 2002).

Within the Rio Grande drainage of the southwestern United States and northern Mexico, numerous historically widespread and abundant native fishes are now less common and occupy a fraction of their historical ranges (Hubbs et al. 1977, Bestgen and Platania 1991, Edwards and Contreras-Balderas 1991, Edwards et al. 2002, Calamusso et al. 2005, Hoagstrom et al. 2008). For example, Rio Grande silvery minnow (Hybognathus amarus), speckled chub (Macrhybopsis aestivalis), Rio Grande shiner (Notropis jemezanus), and blue sucker (Cycleptus elongatus) are extirpated from numerous reaches (Anderson et al. 1995, Platania and Altenbach 1998); and phantom shiner (Notropis orca) and Rio Grande bluntnose shiner (Notropis simus simus) are extinct (Bestgen and Platania 1990, Hubbs et al. 2008). Declines in abundance and distribution of some Rio Grande fishes coincided with increases in habitat generalist and lentic-adapted species such as red shiner (Cyprinella lutrensis), fathead minnow (Pimephales promelas), gizzard shad (Dorosoma cepedianum), and western mosquito fish (Gambusia affinis) after stream alteration throughout the Rio Grande watershed (Calamusso et al. 2005). However, despite well-documented changes in species abundances and distributions, mechanisms contributing to the decrease of some native fishes and increase of other native or nonnative fishes remain unclear. Additional research is needed to establish the relationship between the ecology of local fish communities and the anthropogenic alterations occurring throughout the basin.

Ichthyofaunal changes in the Rio Grande are associated with anthropogenic activities that modify instream habitat and cause concern for the long-term persistence of endemic taxa. Construction of reservoirs, channel straightening, water diversions for agricultural purposes, reduced stream-flow quantity, degraded water quality, and introduction of nonnative species are common in the Rio Grande (Edwards et al. 2002, Calamusso et al. 2005). In some reaches, the mainstem river is completely dewatered because of agricultural and municipal withdrawals (Calamusso et al. 2005); and in other reaches, poor water quality and chemical pollution prompt advisories against water contact and fish consumption (Owens and Niemeyer 2006). Stream fragmentation is thought to be related to the extirpation of fishes belonging to the pelagic-spawning reproductive guild, and only a few remaining populations persist in relatively long fragments $(>100 \mathrm{~km}$ in length; Dudley and Platania 2007). Such extensive alterations call into question the feasibility of conserving or restoring intact fish communities within highly modified mainstem reaches (Calamusso et al. 2005). Less impacted river reaches, including the Big Bend National Park reach of the Rio Grande, provide the opportunity to assess the ecology of relatively intact local fish communities (Moring 2002) or, more specifically, to assess habitat associations and suitability for declining or imperiled species (Helfman 2007). Knowledge of habitat associations and suitability is a primary step toward conserving imperiled species (Bond and Lake 2003). This knowledge provides targets for habitat conservation and restoration (Lake et al. 2007) and is necessary for ecoregions such as the Rio Grande where empirical data for instream flow requirements are lacking (Sansom 2008).

The goal of this study was to quantify intraannual variation in the habitat ecology of local fish communities in the Big Bend reach of the Rio Grande. We specifically sought to assess occurrence and habitat associations of smallbodied species that are extirpated from Rio Grande reaches separated from the Big Bend region by impoundments and that occur in portions of New Mexico and the Rio Grande terminus near the Gulf of Mexico (e.g., Gido et al. 1997). Historical and contemporary literature 


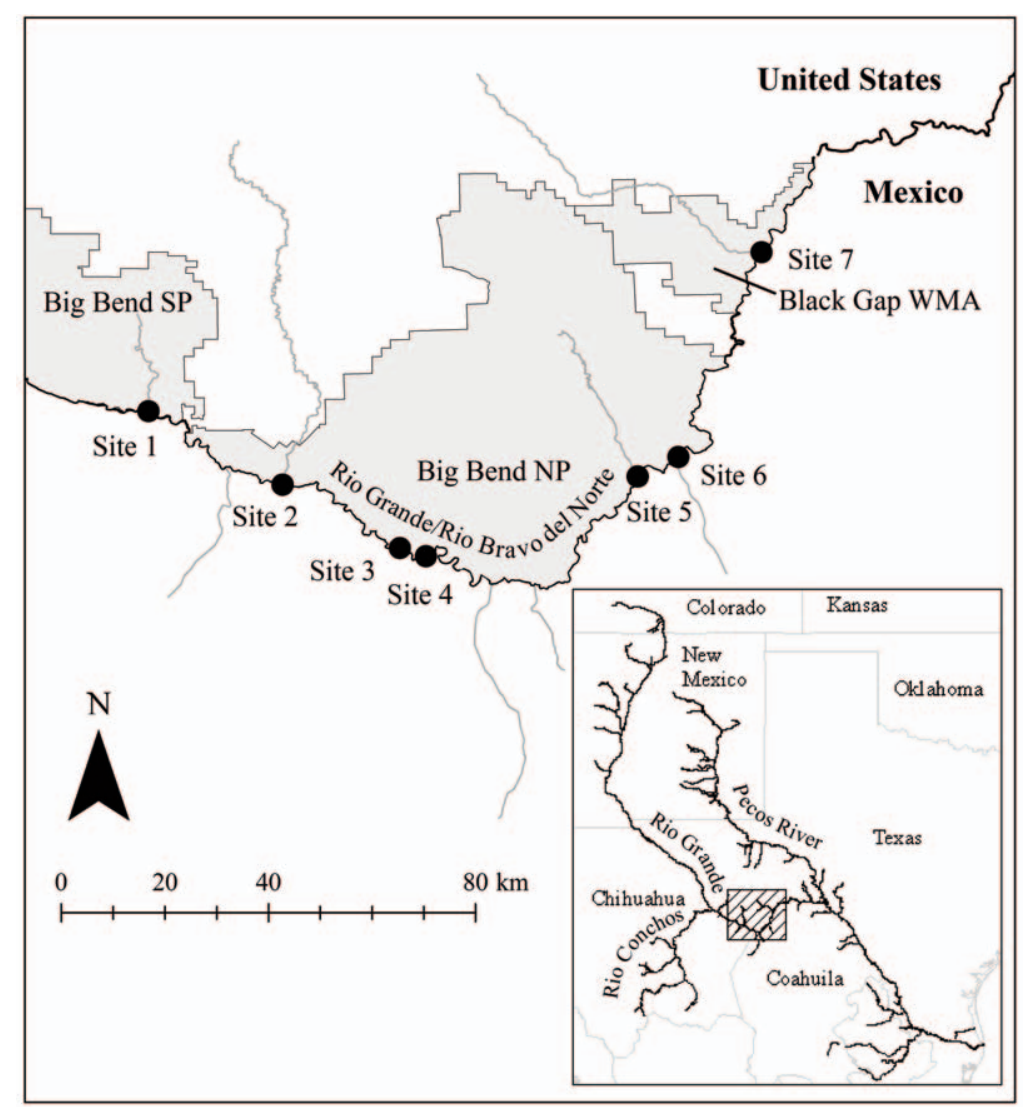

Fig. 1. Mainstem Rio Grande sites sampled monthly, January-December 2006. Site 1 was accessed through Big Bend State Park (SP), sites 2-6 through Big Bend National Park (NP), and Site 7 through Black Gap Wildlife Management Area (WMA).

suggests that many imperiled, small-bodied species inhabit shallow areas throughout a suite of geomorphic units in the Big Bend region (Hubbs et al. 1977, Moring 2002), so we targeted wadeable habitats accessible from within or near Big Bend National Park. Our objectives were to (1) quantify occurrence, abundance, and habitat associations among local communities, (2) assess local community and habitat change with respect to intra-annual variation in streamflow, and (3) describe relationships among abundant small-bodied taxa in terms of current velocity suitability and associated implications for community dominance.

\section{Methods}

\section{Study Area}

The Big Bend reach of the Rio Grande generally refers to a section of the international boundary from the confluence of the Rio Conchos (Chihuahua, Mexico) to the confluence of the Pecos River (Texas, USA). Aquatic and terrestrial environments within the reach are largely under the jurisdiction of various state and federal agencies, including Big Bend Ranch State Park (SP), Cañón de Santa Elena Protected Natural Area, Big Bend National Park (NP), Maderas del Carmen Protected Natural Area, Rio Grande Wild and Scenic River, and Black Gap Wildlife Management Area (WMA). Despite large-scale habitat degradation and homogenization throughout the basin, a diversity of habitats persist in the Big Bend reach, including multiple geomorphic units (e.g., riffles, runs, and pools), limited areas of braided channels, and substrates ranging from silt to boulders (Hubbs et al. 1977, Moring 2002). For this study, 7 sampling sites in a $200-\mathrm{km}$ reach were selected because 
of available habitat heterogeneity and accessibility (Fig. 1). Mainstem sites were located near the confluence of Contrabando Creek (Site 1; $29^{\circ} 16^{\prime} 44^{\prime \prime} \mathrm{N}, 103^{\circ} 50^{\prime} 35^{\prime \prime} \mathrm{W}$ ), downstream from Santa Elena Canyon (Site 2; $29^{\circ} 09^{\prime} 52^{\prime \prime} \mathrm{N}$, $\left.103^{\circ} 36^{\prime} 34^{\prime \prime} \mathrm{W}\right)$, near the USGS gaging station (Site 3; $29^{\circ} 01^{\prime} 57^{\prime \prime} \mathrm{N}, 103^{\circ} 23^{\prime} 15^{\prime \prime} \mathrm{W}$ ), near Johnson Ranch campground of Big Bend NP (Site 4; $\left.29^{\circ} 01^{\prime} 17^{\prime \prime} \mathrm{N}, 103^{\circ} 22^{\prime} 11^{\prime \prime} \mathrm{W}\right)$, near the confluence of Tornillo Creek (Site 5; $29^{\circ} 10^{\prime} 41^{\prime \prime} \mathrm{N}$, $\left.102^{\circ} 59^{\prime} 46^{\prime \prime} \mathrm{W}\right)$, upstream from Boquillas Canyon (Site $6 ; 2^{\circ} 11^{\prime} 56^{\prime \prime} \mathrm{N}, 102^{\circ} 55^{\prime} 02^{\prime \prime} \mathrm{W}$ ), and near the confluence of Maravillas Creek (Site 7; $\left.29^{\circ} 33^{\prime} 45^{\prime \prime} \mathrm{N}, 102^{\circ} 46^{\prime} 35^{\prime \prime} \mathrm{W}\right)$. Study sites contained a mixture of wadeable geomorphic units characterized by a diversity of substrate types, depths up to $1.2 \mathrm{~m}$, and current velocities up to $2 \mathrm{~m} \cdot \mathrm{s}^{-1}$. At all sites, riparian vegetation consisted of dense stands of exotic giant reed (Arundo donax) and saltcedar (Tamarix spp.; Moring 2002).

The Rio Grande flow regime in the Big Bend region is influenced by contributions from upstream portions of the Rio Grande proper and the largest tributary in the basin, the Rio Conchos. The Rio Conchos enters the Rio Grande near the city of Presidio, Texas, just upstream of the study area and now contributes $>80 \%$ of water present in the Rio Grande downstream of the confluence (Kim et al. 2002). Patterns in flow variability from the Rio Conchos are driven by monsoonal weather patterns, with high flow events during fall months (August-November) and low base flows during remaining months of the year (Kim et al. 2002). Variability of flow contributions from the upper Rio Grande was historically driven by seasonal snowmelt patterns and was characterized by large flood pulses during spring months before regulation by reservoirs and subsequent storage and withdrawal of water upstream (Dean and Schmidt 2011). Consequently, characteristics of the contemporary flow regime of the Big Bend reach of the Rio Grande are dependent on contributions from the Rio Conchos (Dean and Schmidt 2011).

\section{Sampling Methods}

We sampled fishes and quantified wadeable habitats monthly from January through December 2006 at all sites, with the exception of sites 3 and 4, which were not accessible in July 2006. At each site, we established 4-20 transects. Transects were placed perpendicular to the stream bank and spaced approximately one mean stream width apart (Simonson et al. 1994). Along each transect, we seined (seine dimensions: $3 \mathrm{~m} \times 1.8 \mathrm{~m}$; mesh size $=3.1$ $\mathrm{mm}$ ) discrete geomorphic units (run, riffle, pool, side channel, backwater, or eddy) with 5-mlong seine hauls in a downstream direction. In cases of fast runs and shallow riffles, 5-m kicks into blocking seines were used to sample fish communities. Along each transect, seine hauls were spaced approximately $10 \mathrm{~m}$ apart to avoid disturbing adjacent habitats, and a minimum of 20 seine hauls were conducted on each date (Matthews 1986a). Captured fish were identified to species when practical and released, except for those retained as voucher specimens. Within the area of each seine haul, current velocity $\left(\mathrm{cm} \cdot \mathrm{s}^{-1}\right)$ and depth $(\mathrm{cm})$ were measured from 2 random points, and substrate type at 10 random points was determined based on a modified Wentworth scale (Cummins 1962, McMahon et al. 1996).

\section{Statistical Methods}

Habitat characteristics among sites were described using principal component analysis (PCA; CANOCO version 4.5 (c) Micro Computer Power) to test the hypothesis that multiple habitat parameters differed through space and time (Ahmadi-Nedushan et al. 2006). For PCA, quantitative data (mean current velocity, mean depth, and percent substrate) were $Z$ score transformed and qualitative data (geomorphic unit) were represented by dummy variables (Krebs 1999). Habitat similarities among sites and months were assessed by testing for differences among mean sampling scores along the principal components that described the most variation in the data (axes I and II) using single factor analyses of variance (ANOVA) and Fisher's test for least significant differences (LSD; $\alpha=0.05$ ). Species-habitat associations were described using canonical correspondence analysis (ter Braak 1986). Relationships between environmental factors and species abundance and distribution were verified using an ordinal cross-validation technique following the methods of Hallgren et al. (1999). Relative importance of site, season, and environmental factors in determining species abundance and distribution were tested using variance-partitioning techniques in canonical correspondence analysis (Bean et al. 2007). For canonical correspondence analysis variance 

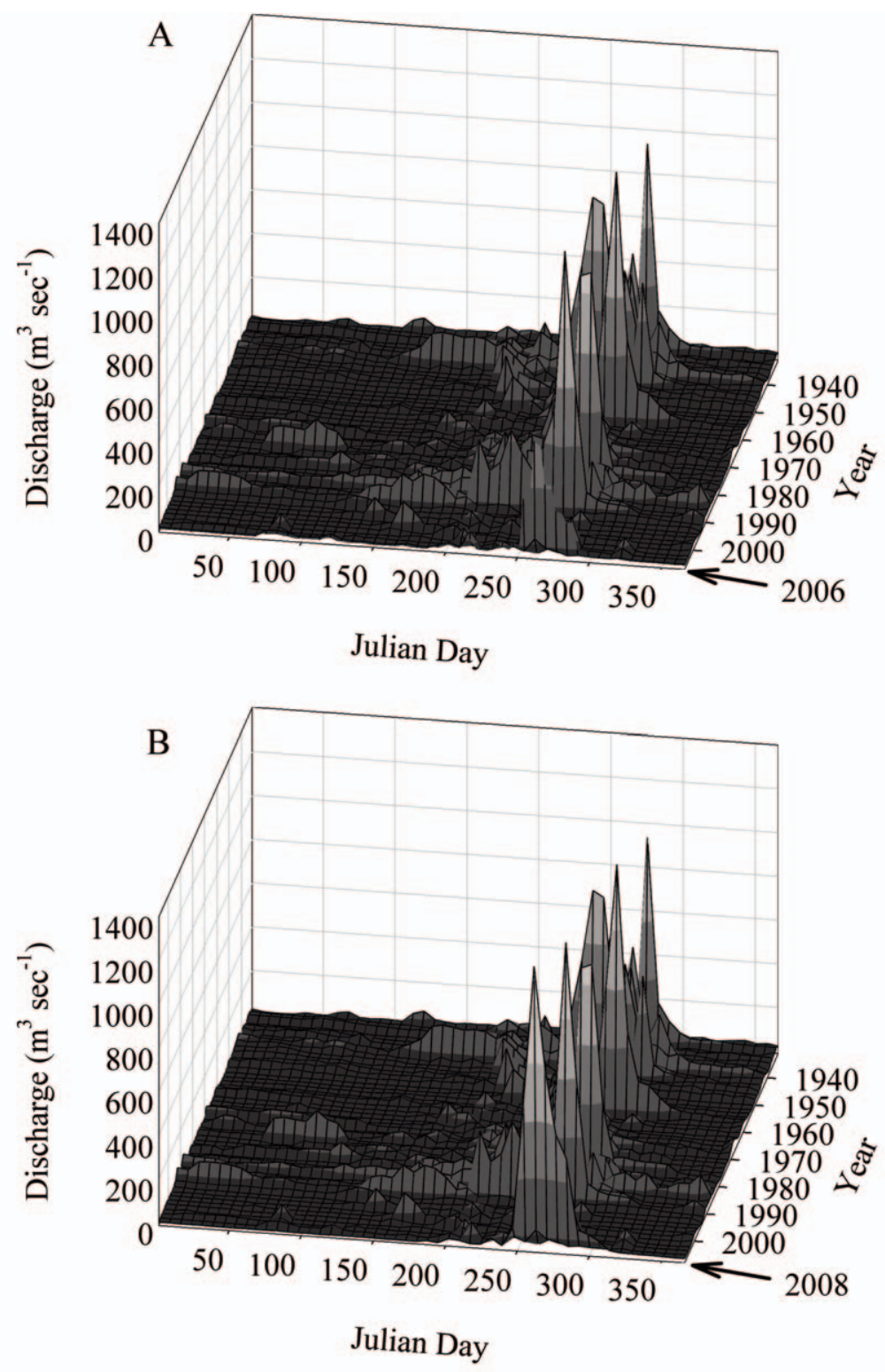

Fig. 2. Flow history for the Big Bend reach of the Rio Grande based on daily streamflows $\left(\mathrm{m}^{3} \cdot \mathrm{s}^{-1}\right)$ recorded at the International Boundary and Water Commission gage near Presidio, Texas, USA, and Ojinaga, Chihuahua, Mexico (gage \#083742.00). The long-term pattern of monsoonal flooding is illustrated, including year of data collection (2006; A) and flooding that has occurred since $(2008 ; \mathrm{B})$.

partitioning, we defined seasons according to monsoonal precipitation cycles in the arid southwestern USA and north central Mexico as preflood (January-July), flood (AugustOctober), and postflood (November-December; Kim et al. 2002; Fig. 2). Because some fishes are thought be displaced or killed by high current velocities during flooding (Collins et al. 1981, Harvey 1987, Minckley and Meffe 1987), we tested suitability of current velocities for 3 abundant small-bodied species $(C$. lutrensis, Tamaulipas shiner [Notropis braytoni], and M. aestivalis) using KolmogorovSmirnov (KS) tests to describe differences in expected and observed abundances among current velocities. Expected values for KS 
TABLE 1. Species, canonical correspondence analysis (CCA) code, and total number and overall density $\left(\right.$ fish $\left.\cdot 100 \mathrm{~m}^{-2}\right)$ of fishes captured from the Rio Grande/Rio Bravo del Norte at 7 sites in the Big Bend National Park region. Species marked with asterisks are listed as imperiled or threatened by Hubbs et al. (2008). Two Lepomis species (L. megalotis and L. macrochirus) were collected (total $S=20$ ), but individuals $<12 \mathrm{~mm}$ were not identified to species.

\begin{tabular}{|c|c|c|c|c|c|c|c|c|c|}
\hline Species & CCA code & Total & Site 1 & Site 2 & Site 3 & Site 4 & Site 5 & Site 6 & Site 7 \\
\hline Lepisosteus osseus & Lep oss & 15 & & 0.01 & 0.05 & 0.06 & 0.02 & 0.04 & 0.14 \\
\hline Cyprinella lutrensis & Cyp lut & 4895 & 16.06 & 12.42 & 8.18 & 17.10 & 13.71 & 19.36 & 7.40 \\
\hline Cyprinus carpio & Cyp car & 69 & 0.08 & 0.53 & 0.16 & 0.08 & 0.15 & 0.11 & 0.09 \\
\hline Macrhybopsis aestivalis ${ }^{*}$ & Mac aes & 333 & 0.44 & 1.71 & 1.17 & 1.28 & 0.67 & 0.84 & 0.07 \\
\hline Notropis braytoni ${ }^{*}$ & Not bra & 3695 & 4.76 & 7.18 & 3.05 & 5.66 & 21.78 & 20.73 & 7.47 \\
\hline Notropis chihuahua* & Not chi & 13 & & 0.17 & & 0.02 & & & \\
\hline Notropis jemezanus ${ }^{*}$ & Not jem & 5 & & 0.04 & & 0.02 & 0.02 & & \\
\hline Rhinichthys cataractae & Rhi cat & 38 & & 0.54 & & & & & \\
\hline Carpiodes carpio & Car car & 433 & 0.42 & 2.73 & 0.23 & 1.81 & 1.63 & 0.33 & 0.21 \\
\hline Ictiobus bubalus & Ict bub & 2 & & & & 0.02 & & 0.02 & \\
\hline Cycleptus elongatus* & Cyc elo & 22 & 0.02 & 0.03 & & & 0.02 & 0.31 & 0.09 \\
\hline Astyanax mexicanus & Ast mex & 141 & 0.13 & 0.04 & 0.18 & 0.02 & 0.91 & 0.53 & 1.05 \\
\hline Ictalurus furcatus & Ict fur & 171 & 0.55 & 0.16 & 0.18 & 0.47 & 0.63 & 0.64 & 0.78 \\
\hline Ictalurus punctatus & Ict pun & 249 & 0.40 & 0.43 & 0.47 & 0.34 & 1.87 & 0.77 & 0.44 \\
\hline Pylodictis olivaris & Pyloli & 31 & 0.02 & 0.14 & 0.21 & & 0.02 & 0.13 & 0.11 \\
\hline Fundulus zebrinus & Fun zeb & 54 & & 0.54 & 0.08 & 0.04 & 0.17 & & 0.02 \\
\hline Gambusia affinis & Gam aff & 315 & 0.50 & 0.40 & 1.80 & 1.36 & 1.22 & 0.79 & 0.37 \\
\hline Menidia beryllina & Men ber & 64 & & 0.54 & 0.03 & 0.02 & 0.21 & 0.13 & 0.14 \\
\hline Lepomis spp. & Lep spp & 20 & 0.02 & 0.04 & 0.13 & 0.12 & 0.02 & & 0.09 \\
\hline Total number individuals & & 10,565 & 1225 & 1938 & 611 & 1441 & 2511 & 2033 & 806 \\
\hline Species richness $(S)$ & & 20 & 12 & 18 & 14 & 16 & 16 & 14 & 15 \\
\hline Diversity (1-D) & & 0.66 & 0.49 & 0.72 & 0.68 & 0.6 & 0.64 & 0.6 & 0.67 \\
\hline Number of seine hauls & & 2393 & 349 & 467 & 256 & 338 & 389 & 303 & 291 \\
\hline
\end{tabular}

tests were calculated as the total number of individuals collected among habitats if distribution was uniform, and observed values were calculated as the total number of individuals captured within current velocity frequency bins calculated using the Sturges (1926) equation (Williams and Bonner 2006). Although river carpsucker (Carpiodes carpio) was the third most abundant species, we excluded it from further testing because $99 \%$ of those captured were juveniles $(<200 \mathrm{~mm}$ TL; Jester 1972, Ross 2001), opting instead to provide more information for a Rio Grande endemic (M. aestivalis).

Differences in fish community composition among sites and months were tested using analysis of similarity (ANOSIM). Bray-Curtis similarity matrices (Bray and Curtis 1957) created in Primer 6.1.6 were tested with ANOSIM ( $\alpha=0.05$; 9999 permutations) using permutations to assess average rank dissimilarity in fish density between sites and months (Clarke 1993, Bean et al. 2007). Abundances of individual species among sites and months were quantified by calculating density (fish $\cdot 100 \mathrm{~m}^{-2}$ ) for species collected within each seine haul. Before analysis, density data were fourth-root transformed to standardize contributions of high- and low-abundance species (Clarke and Green 1988). Spatiotemporal variability in fish communities was quantified by plotting mean similarities among all pairwise site comparisons for each month of sampling (Gido et al. 1997), and differences were assessed using ANOVA and Fisher's LSD. Similarly, changes in proportional density (density of individual species / density of all species) summed across sites were plotted by month for the 3 most dominant small-bodied species and overlaid with discharge values to illustrate changes in dominance that corresponded with changes in discharge.

\section{RESUlTS}

We collected a total of 10,565 fishes representing 20 species from 7 sites along the Big Bend reach of the Rio Grande during monthly sampling in 2006 (Table 1). Two Lepomis species (Lepomis megalotis and Lepomis macrochirus) were collected (total $N=20$ ) but individuals $<12 \mathrm{~mm}$ were not identified to species. Therefore we grouped larvae and adult individuals into Lepomis spp. Site 1 had the lowest species richness $(S=12)$ and diversity $(1-\mathrm{D}=0.49)$, whereas Site 2 had the highest species richness $(S=18)$ and diversity $(1-\mathrm{D}=0.72)$. We 
TABLE 2. Habitat variable loadings, percent explained variance, and distribution of mean site and monthly scores along principal component (PC) I and II for habitat parameters measured in the Rio Grande/Rio Bravo del Norte. Standard deviations are in parentheses. Bolded values indicate parameters shown in Figure 3 and letters indicate statistical differences $(\alpha=0.05)$ among PC scores.

\begin{tabular}{|c|c|c|}
\hline Parameter & PC I & PC II \\
\hline $\begin{array}{l}\text { Current velocity } \\
\left(\mathrm{m} \cdot \mathrm{s}^{-1}\right)\end{array}$ & -1.163 & -1.288 \\
\hline Depth $(\mathrm{m})$ & -1.432 & 0.619 \\
\hline Run & -2.248 & 0.428 \\
\hline Riffle & 1.396 & -1.537 \\
\hline Side channel & 0.929 & 0.561 \\
\hline Backwater & 0.859 & 0.816 \\
\hline Pool & 0.740 & 0.595 \\
\hline Eddy & 0.499 & 0.212 \\
\hline Boulder (\%) & 0.278 & -0.274 \\
\hline Cobble (\%) & -0.021 & -2.107 \\
\hline Gravel (\%) & -0.889 & 0.730 \\
\hline Sand $(\%)$ & -0.458 & 0.747 \\
\hline Silt $(\%)$ & 0.952 & 1.841 \\
\hline $\begin{array}{l}\text { Variance } \\
\quad \text { explained }(\%)\end{array}$ & 15.5 & 13.8 \\
\hline Site 1 & $1.107(1.51) \mathrm{a}$ & $-0.146(1.60) \mathrm{c}$ \\
\hline Site 2 & $0.017(1.53) \mathrm{b}$ & $0.101(1.37) \mathrm{b}$ \\
\hline Site 3 & $-0.334(1.20) \mathrm{d}$ & $-0.791(0.87) \mathrm{d}$ \\
\hline Site 4 & $-0.423(1.52) \mathrm{d}$ & $1.421(0.93) \mathrm{a}$ \\
\hline Site 5 & $-0.009(1.37) \mathrm{bc}$ & $-0.615(1.20) \mathrm{d}$ \\
\hline Site 6 & $-0.345(1.43) \mathrm{d}$ & $-0.054(1.43) \mathrm{bc}$ \\
\hline Site 7 & $-0.199(1.45) \mathrm{cd}$ & $-0.062(1.32) \mathrm{bc}$ \\
\hline Jan & $0.116(0.40) \mathrm{a}$ & $-0.013(0.43) \mathrm{ab}$ \\
\hline Feb & $0.097(0.37) \mathrm{a}$ & $-0.035(0.36) \mathrm{ab}$ \\
\hline Mar & $0.028(0.32) \mathrm{ab}$ & $-0.084(0.34) \mathrm{b}$ \\
\hline Apr & $-0.005(0.47) \mathrm{ab}$ & $0.032(0.34) \mathrm{ab}$ \\
\hline May & $0.066(0.40) \mathrm{ab}$ & $0.030(0.37) \mathrm{ab}$ \\
\hline Jun & $0.035(0.37) \mathrm{ab}$ & $-0.077(0.41) \mathrm{ab}$ \\
\hline Jul & $-0.069(0.33) \mathrm{ab}$ & $0.004(0.32) \mathrm{ab}$ \\
\hline Aug & $-0.115(0.34) \mathrm{ab}$ & $0.032(0.29) \mathrm{ab}$ \\
\hline Sep & $-0.166(0.33) \mathrm{b}$ & $0.055(0.36) \mathrm{a}$ \\
\hline Oct & $-0.005(0.46) \mathrm{ab}$ & $0.055(0.40) \mathrm{a}$ \\
\hline Nov & $-0.053(0.39) \mathrm{ab}$ & $0.020(0.37) \mathrm{ab}$ \\
\hline Dec & $-0.060(0.38) \mathrm{ab}$ & $0.003(0.36) \mathrm{ab}$ \\
\hline
\end{tabular}

attributed high richness and diversity at Site 2 to the occurrence of uncommon species such as Chihuahua shiner (Notropis chihuahua), N. jemezanus, longnose dace (Rhinichthys cataractae), and C. elongatus. Habitat generalist $C$. lutrensis was the most abundant fish (46\% relative abundance) across sites and months and most abundant at sites $1-4(45 \%-69 \%$ relative abundance). Endemic N. braytoni was second most abundant $(35 \%)$ across sites and months and most abundant at sites $5-7(40 \%-51 \%$ relative abundance). Excluding N. braytoni, imperiled fishes constituted $4 \%$ of the total fish community. Nonnative common carp (Cyprinus carpio), inland silverside (Menidia beryllina), and plains killifish (Fundulus zebrinus) represented $<1 \%$ of the total assemblage, and although exotic blue tilapia (Oreochromis aureus) were not collected, we observed them during a fish kill in December 2006 near Site 2.

Wadeable habitats within the study area consisted of backwater, eddy, pool, riffle, run, and side-channel geomorphic units. Within geomorphic units, substrate particle sizes ranged from silt $(0.0038 \mathrm{~mm})$ to boulder $(>256 \mathrm{~mm})$, depths ranged between 5 and $110 \mathrm{~cm}$, and current velocities were $0-1.8 \mathrm{~m} \cdot \mathrm{s}^{-1}$. The first 2 principal components (PCs) of PCA explained $29.3 \%$ of variation in habitat parameters (Table 2). The remaining PCs explained little additional variation (PC III 9\%; PC IV $8 \%$ ) and were disregarded. The first principal component explained $15.5 \%$ of variation and represented a geomorphic unit, depth, and velocity gradient. Habitat parameters with large negative loadings along PC I were characterized by run geomorphic units (loading $=-2.24$ ), greater depths (-1.43), and greater current velocities (-1.16); whereas habitat parameters with large positive loadings were characterized by riffle geomorphic units (1.39), silt substrate (0.95), and side-channel geomorphic units (0.93). The second PC explained $13.8 \%$ of variation and represented a substrate, geomorphic unit, and velocity gradient. Habitat parameters with large negative loadings along PC II were characterized by cobble substrate $(-2.11)$, riffle geomorphic units $(-1.54)$, and greater current velocities $(-1.29)$; whereas habitat parameters with large positive loadings were characterized by silt substrate (1.84) and backwater geomorphic units (0.82). Sites differed among habitat parameters along PC I $\left(F_{6,2386}=45.0, P<\right.$ $0.01)$ and PC II $\left(F_{6,2386}=101.7, P<0.01\right)$ and by month along PC I $\left(F_{11,2386}=9.25, P<\right.$ $0.01)$ and PC II $\left(F_{11,2386}=3.14, P<0.01\right)$. Site 1 consisted of riffle and side-channel geomorphic units; site 4 consisted primarily of backwater geomorphic units with silt substrate; sites 3 and 5 consisted primarily of riffle geomorphic units, cobble substrate, and higher current velocities; and sites 2, 6, and 7 had greatest habitat heterogeneity and consisted of all available geomorphic units and substrate sizes (Fig. 3A). Monthly variability in available habitat characteristics was less notable than variation among sites (Fig. 3B). However, March and June were characterized by riffle geomorphic units with cobble substrate and higher current velocities, whereas October and September 

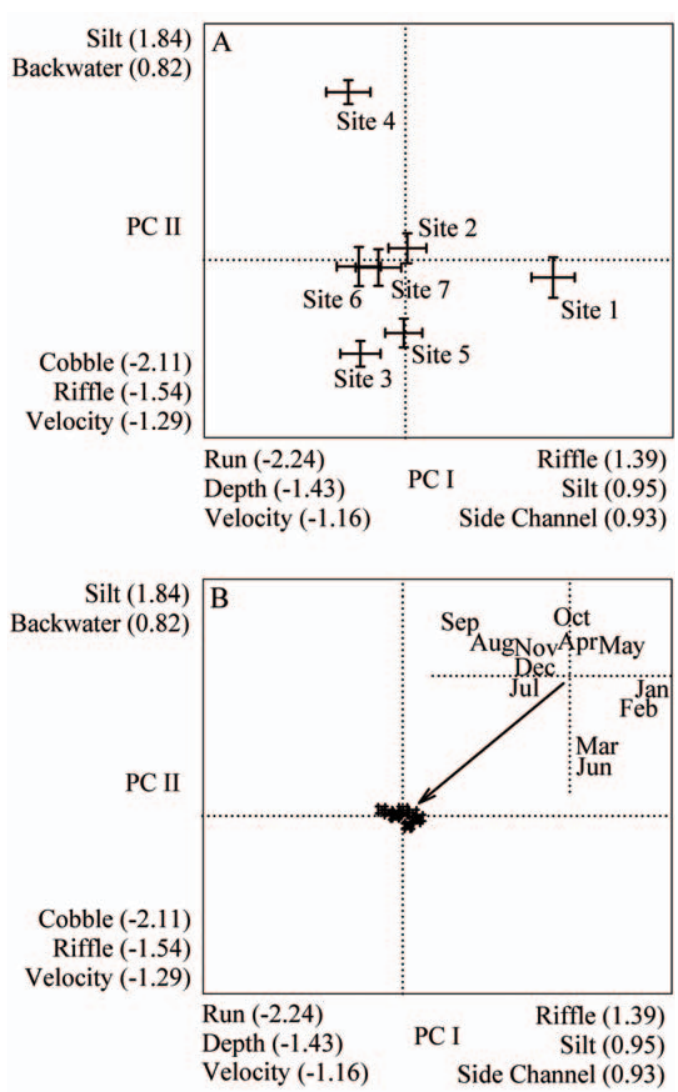

Fig. 3. Principal components analysis biplots for Rio Grande/Rio Bravo del Norte sites sampled monthly, January-December 2006: A, spatial variation among 7 sites; B, temporal variation among 12 months for habitat gradients along principal component (PC) I and II Dotted lines represent the origin (panels are scaled similarly) and points represent mean $( \pm \mathrm{SE})$ PC scores.

were predominantly characterized by run geomorphic units with greater depths and higher current velocities (see Table 2 for all pairwise comparisons).

We characterized species-habitat associations using canonical correspondence analysis. Physical habitat, season, and site collectively explained $6.2 \%$ of the total taxonomic variability within the sampled fish assemblage, partitioned among physical habitat $(4 \% ; P<0.01)$, season $(1.6 \%, P<0.01)$, site $(0.4 \%, P<0.01)$, and 2 and 3-way interactions $(0.2 \%)$. Ordinal crossvalidation identified habitat parameters that explained significant $(P<0.05)$ portions of species distributions, including current velocity (14\% of explained variation), flood season (8\%), backwater geomorphic units $(7 \%)$, depth $(5 \%)$,

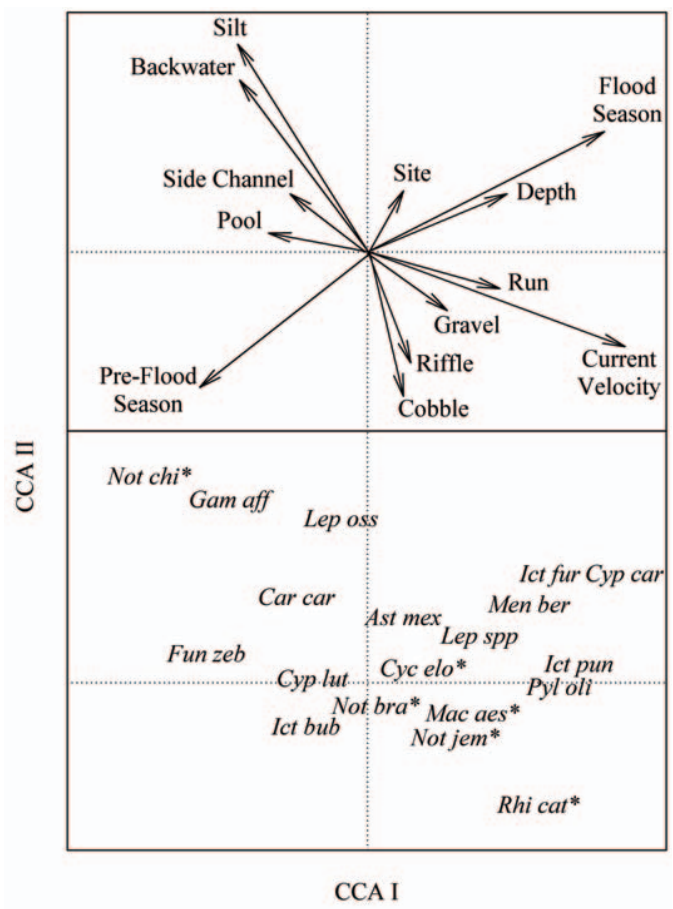

Fig. 4. Canonical correspondence analysis biplots illustrating species-habitat associations along canonical correspondence axis (CCA) I and II for fish and habitat data collected from 7 Rio Grande/Rio Bravo del Norte sites, JanuaryDecember 2006. Asterisks denote imperiled species listed by Hubbs et al. (2008).

site $(4 \%)$, and silt substrate $(3 \%)$. Among these parameters, those with large negative loadings along canonical correspondence axis (CCA) I were preflood season $(-0.45)$, silt substrate $(-0.34)$, backwater geomorphic units $(-0.32)$, and pool geomorphic units $(-0.25)$. Parameters with large positive loadings were current velocity (0.69), depth (0.37), run geomorphic units (0.35), and flood season (Fig. 4). Habitat parameters with large negative loadings along CCA II were cobble $(-0.49)$, preflood season $(-0.47)$, riffle geomorphic units $(-0.37)$, and current velocity $(-0.32)$. Parameters with large positive loadings were silt substrate (0.69), backwater geomorphic units (0.59), and flood season (0.40). Species with strong associations with habitat parameters included M. aestivalis, N. jemezanus, and $R$. cataractae, which associated with riffle to run geomorphic units characterized by gravel substrate and greater current velocities. Blue catfish (Ictalurus furcatus), Cyprinus carpio, and $M$. beryllina indicated strong associations with flood season, and G. affinis indicated 


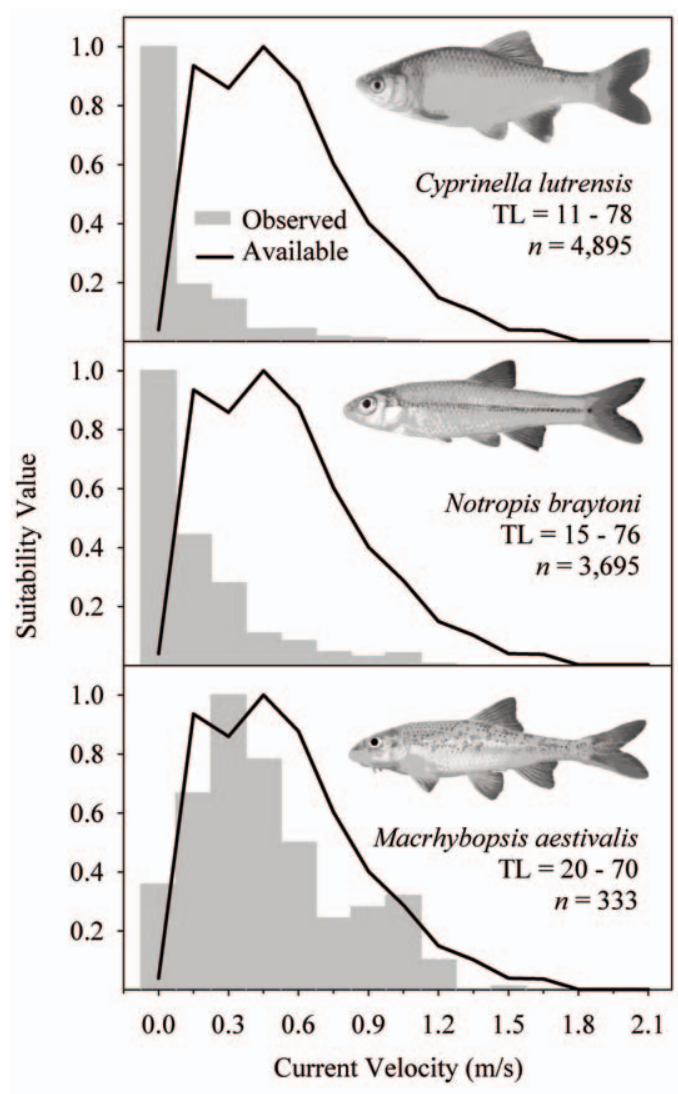

Fig. 5. Current velocity associations and suitability values for 3 dominant fish species collected from the Rio Grande/ Rio Bravo del Norte, January-December 2006. Black lines represent distribution of available current velocities and gray bars represent distribution of observed associations by species. Ranges for total lengths (TL) of captured individuals are shown in $\mathrm{mm} ; n$ is the frequency of occurrence.

strong associations with backwater geomorphic units containing silt substrate. Habitat associations were most general for C. lutrensis and $N$. braytoni, both of which occurred near the origin of CCA I and CCA II. The 3 most abundant small-bodied species collected during the study-C. lutrensis, N. braytoni, and M. aestivalis-partitioned along a current velocity gradient. Cyprinella lutrensis frequency distribution among current velocities differed from expected $(\mathrm{D}=0.76, P<0.001)$ and indicated association with slow current velocities; $N$. braytoni distribution differed from expected $(\mathrm{D}=0.62, P<0.001)$ and indicated association with increasingly intermediate velocities; and $M$. aestivalis distribution differed from expected $(\mathrm{D}=0.27, P<0.001)$ and indicated association with relatively faster current velocities (Fig. 5).

Community composition differed spatially (among sites) and temporally (among months) over the course of the study. Analysis of similarity (ANOSIM) detected differences in community composition among sites (global $\mathrm{R}=$ $0.01, P<0.01$ ), and the magnitude of these differences varied temporally. Mean percent similarity among all possible pairwise site comparisons differed through time $\left(F_{11,229}=40.37\right.$, $P<0.01)$. During January and February, mean similarity among sites was $4.6 \%-4.8 \%$ but increased to $7.9 \%$ in March and increased again during April through July when similarity values ranged from $14.7 \%$ to $23.9 \%$ (Fig. 6 A). Following large flood pulses in August, which marked the onset of the monsoonal flooding season, mean similarity among sites significantly decreased to $7.3 \%$. Mean similarity values continued to decrease during September and October (4.4\% and $4.0 \%$, respectively) and November and December (2\% and $1.4 \%$, respectively). Higher percent similarity among sites during the months between April and July corresponded with increases in proportional density of $C$. lutrensis and decline of $N$. braytoni, while mean densities of $M$. aestivalis remained relatively stable (Fig. 6B). Monthly density among all species correlated most with changes in mean density of $C$. lutrensis $(r=0.97, P<$ $0.01)$ and to a lesser extent $N$. braytoni $(r=0.84$, $P<0.01)$, but not with $M$. aestivalis $(r=0.46, P$ $=0.13$ ), indicating dominance by $C$. lutrensis and $N$. braytoni. During all months from January through July, proportional density of $C . l u$ trensis outranked N. braytoni; however, proportional density of $C$. lutrensis declined notably between July and August, after the onset of monsoonal flooding. Following the largest flood pulse observed during 2006 (September, 186 $\mathrm{m}^{3} \cdot \mathrm{s}^{-1}$ ), proportional density of $N$. braytoni outranked C. lutrensis for the remainder of the study.

\section{Discussion}

Fish communities at 7 sites in the Big Bend reach of the Rio Grande exhibited spatial and temporal variation in 2006. During this time, streamflows followed a consistent pattern of increased discharges in fall associated with monsoonal weather patterns in the region. Similar habitat types persisted through time despite 

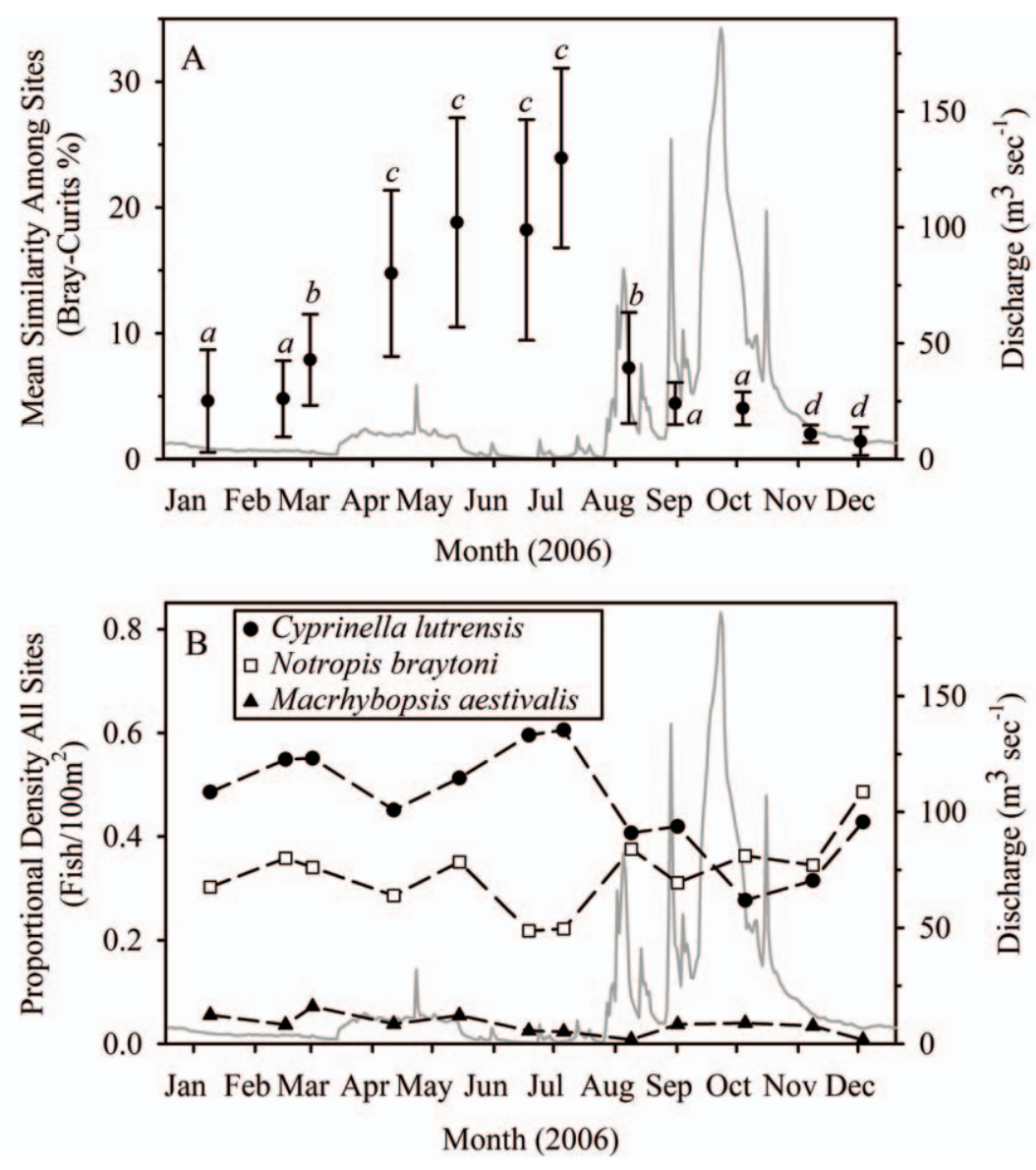

Fig. 6. Spatiotemporal variability in fish communities at 7 Rio Grande/Rio Bravo del Norte sites, January-December 2006: A, monthly mean $( \pm \mathrm{SD})$ and Bray-Curtis percent similarity for all pairwise comparisons among sites (solid circles) and daily discharge $\left(\mathrm{m}^{3} \cdot \mathrm{s}^{-1}\right.$; gray line). Letters indicate significant $(\alpha=0.05)$ differences among means; B, monthly proportional density across all sites (fish $\cdot 100 \mathrm{~m}^{-2}$ ) for 3 dominant small-bodied species and daily discharge.

large changes in flow regime, as evidenced by greater spatial variation relative to temporal variation detected during PCA procedures. Consequently, temporal differences in community composition were likely influenced by flow regime, often regarded as the master variable in stream ecosystems (Poff and Ward 1989), whereas spatial differences were likely related to available habitats among sampling sites and species-specific associations with habitat components. These conclusions are supported by species-specific associations we detected in canonical correspondence analysis that illustrated seasonal and spatial associations among fishes. For example, imperiled species indicated associations with higher current velocities in run to riffle geomorphic units dominated by gravel and cobble substrates with little silt; imperiled species tended to occur at higher densities among sites exhibiting a mix of these habitats (i.e., sites 2,6 , and 7).

Species-specific habitat associations were dependent upon habitat heterogeneity within the Big Bend reach of the Rio Grande, especially for imperiled species. Many of the imperiled Rio Grande fishes listed by Hubbs et al. (2008) and collected during this study were associated with gravel substrates in run to riffle geomorphic units with greater current velocities. These species were C. elongatus, M. aestivalis, N. braytoni, N. jemezanus, and R. cataractae. Although canonical correspondence analysis explained only $6.2 \%$ of variation among 2393 seine hauls, the resulting gradients are ecologically relevant based on Økland's (1999) conclusion that even low levels of explained percent variation can 
establish ecologically meaningful gradients. Cross-validation techniques indicated that habitat variables explained a significant portion of taxonomic variation. Some potential causes for the observed low levels of explained variation include processes operating at larger spatial scales (e.g., a riverscape perspective) or environmental parameters not measured during our study. For example, the only imperiled species not listed above but collected during this study was $N$. chihuahua, a species known to inhabit tributary streams and disperse infrequently into mainstem habitats (Edwards et al. 2002). Canonical correspondence analysis classified this species as associated with backwaters characterized by silt substrate, but other factors such as distance to nearest tributary might have explained the occurrence of this species more appropriately. Cyprinella lutrensis dominance at upstream sites and $N$. braytoni dominance at downstream sites is another example of a pattern that our environmental data were likely not capable of explaining. Based on broad physiological tolerances of C. lutrensis (Matthews 1986b) and occurrence of poor water quality and documented fish kills in upstream reaches of the Big Bend reach of the Rio Grande (USGS 2004), reduced abundance of $C$. lutrensis at downstream sites might be an artifact of longitudinal improvement of water quality and the return of a more natural fish assemblage (Kinsolving and Bain 1993). Regardless, our findings support the assertion that habitat heterogeneity is correlated with increased species diversity (Guégan et al. 1998), and preservation of heterogeneity is likely necessary for imperiled species conservation (Lake et al. 2007), which might explain why the Big Bend reach maintains a relatively intact fish assemblage.

Fish community composition in the Big Bend reach was correlated with high seasonal streamflows associated with monsoonal precipitation. During the preflood season, streamflows ranged between 0.22 and $31.90 \mathrm{~m}^{3} \cdot \mathrm{sec}^{-1}$, and assemblage composition was dominated by C. lutrensis and N. braytoni. During the flood season, streamflows ranged from 8.7 to 186.0 $\mathrm{m}^{3} \cdot \mathrm{s}^{-1}$, and density decreased by $48.0 \%$ for C. lutrensis and $24.2 \%$ for N. braytoni. Conversely, during the flood season, density was 4 times greater for Cyprinus carpio, 3 times greater for I. furcatus, 8 times greater for I. punctatus, and 1.5 times greater for M. beryllina. Based on the susceptibility of C. lutrensis, Cyprinus carpio, I. furcatus, I. punctatus, and similar species to displacement or mortality during high streamflows (Minckley and Meffe 1987), we suspect that observed density decreases for C. lutrensis, N. braytoni, and river carpsucker (Carpiodes carpio) were related to downstream displacement (Collins et al. 1981) and that observed density increases for Cyprinus carpio, I. furcatus, I. punctatus, and M. beryllina were likely related to transport from upstream reservoirs during water releases (Ward and Stanford 1979, Schultz et al. 2003). Over $80 \%$ of water in the Big Bend region of the Rio Grande enters from the Rio Conchos Basin of Mexico, where monsoonal precipitation events during the flood season cause inundation of reservoirs (Edwards et al. 2002, Kim et al. 2002), and large-scale water releases from reservoirs likely transported many individuals from upstream portions of the Rio Conchos (e.g., Minckley and Meffe 1987).

Large flood pulses during the monsoon season correlated with dynamic changes in dominant species within communities, despite consistency of sampled habitats. Notropis braytoni proportional density indicated little change during the onset of monsoonal flooding during August-November, whereas C. lutrensis density decreased until the postflood season (November-December). Monsoonal flooding in the Big Bend region typically begins during late July and continues through late October. The timing of these flood pulses combined with life history attributes and habitat associations of C. lutrensis and N. braytoni might explain the observed changes in dominance during the postflood season. Age-0 cyprinids are susceptible to downstream transport during flooding because of small body size and poor swimming ability, but susceptibility to displacement decreases with ontological growth (Harvey 1987). Spawning seasons differ for C. lutrensis (April-September; Farringer et al. 1979) and N. braytoni (February-August; T. Heard, unpublished data), and these differences might allow for an additional month of growth for $\mathrm{N}$. braytoni before the onset of monsoonal flooding. Earlier spawning is advantageous in that individuals hatched early in a reproductive season exhibit greater growth rates compared to individuals hatched during the later part of a reproductive season (Durham and Wilde 2005), and early spawning may offer additional benefits by allowing individuals to achieve a larger body size before arrival of flood pulses during the flood season. 
From a habitat suitability standpoint, N. braytoni was more tolerant of higher current velocities than was $C$. lutrensis, as evidenced by the separation of the 2 species along CCA I and by frequency distributions of observed current velocity associations. These observed habitat associations, combined with the coincidental onset of the flood season and declines in $C$. $l u$ trensis proportional density, support published accounts of natural (and dynamic) flow regimes benefiting native and endemic species more than habitat generalist or introduced species (Propst and Gido 2004). Moreover, persistent low-flow conditions typically favor nonnative or native-invasive species by removing displacing floods and effectively limiting habitat heterogeneity that might otherwise be necessary for the persistence of native or imperiled species (Scott and Helfman 2001, Propst and Gido 2004, Perkin and Bonner 2011).

The fish assemblage in the Big Bend reach of the Rio Grande maintains high integrity compared to assemblages in other reaches in the basin. Exotic fishes comprise $>50 \%$ of species richness in the upper reaches of the Rio Grande from its headwaters downstream to the Big Bend reach (Calamusso et al. 2005), 37\% of species richness and $63 \%$ of relative abundance from Amistad Reservoir to Falcon Reservoir downstream of the Big Bend reach, and $33 \%$ of species richness and $71 \%$ of relative abundance downstream from Falcon Reservoir to Hidalgo, Texas (M. Bean, Texas Parks and Wildlife Department, and T. Bonner, unpublished data). Imperiled taxa downstream of Big Bend reach have a relative abundance of $<5 \%$. In contrast, $>30 \%$ (6 of 19 species) of the Big Bend reach fish assemblage sampled during this study consisted of imperiled species, which collectively constituted a relative abundance of $39 \%$. Exotic species constituted $<2 \%$ of the sampled assemblage.

This pattern of imperiled species persistence is likely related to the relatively intact nature of the river in the Big Bend region. For example, stream fragmentation is implicated in declines and extirpations of species in many Rio Grande Basin fragments $<100 \mathrm{~km}$ in length (Dudley and Platania 2007), but the distance between Caballo Dam (upstream of the study reach) and Amistad Dam (downstream) is $>1000 \mathrm{~km}$. Complete dessication of the Rio Grande near the city of El Paso, Texas, is associated with water withdrawal and retention
(Calamusso et al. 2005), but stable base flows of at least $12 \mathrm{~m}^{3} \cdot \mathrm{sec}^{-1}$ persist at the International Boundary and Water Commission (IDWC) streamflow gage near Presidio, Texas, USA, and Ojinaga, Chihuahua, Mexico (gage \#083742.00). Collectively, these factors contribute to instream habitat, stream connectivity, and streamflow regime attributes that allow the persistence of imperiled species.

Reductions in abundance and distribution are widespread for imperiled freshwater fishes (Jelks et al. 2008) and coincide with hydrologic alteration in the Rio Grande (Small et al. 2009). Despite persistence of monsoonal flood seasons, anthropogenic alteration of flow regime has caused substantial changes in stream morphology and instream habitat availability in the Big Bend reach (Dean and Schmidt 2011). Channel width has been reduced by $36 \%-52 \%$ since as early as the 1940s, while vertical accretion within floodplains and propagation of exotic riparian vegetation have caused increased bank sedimentation and narrower channels with steeper banks (Schmidt et al. 2003, Dean and Schmidt 2011). Reduction in channel width and increased bank slope effectively limit abundance and availability of shallow runs and riffles characterized by greater current velocity and gravel to cobble substrates (Poff et al. 1997), which we found were associated with numerous imperiled fishes. Although costly, mechanical removal of exotic riparian vegetation along reaches might improve habitat heterogeneity by increasing sediment transport, providing potential for greater stream widths and reducing evapotranspiration by riparian vegetation by $35 \%$ (Zavaleta 2000). Artificially mimicking natural timing without magnifying or amplifying flood pulses might enhance native fish recruitment via displacement of introduced and habitat generalist species (Gido et al. 1997, Propst and Gido 2004); however, experimental flooding of the highly regulated Grand Canyon reach of the Colorado River did not displace habitat generalist species effectively at low magnitudes, and recurring floods were likely necessary to effectively reduce competition of habitat generalists with native obligate riverine species (Valdez et al. 2001). Even so, each of these management options might ultimately improve the conservation of Big Bend reach fish communities that still maintain imperiled species populations. 
Since completion of this study, a large magnitude flood $\left(1450 \mathrm{~m}^{3} \cdot \mathrm{s}^{-1}\right)$ during the monsoonal flood season of 2008 (Fig. 2B) drastically influenced instream habitat and removed exotic riparian vegetation in much of the Big Bend reach. Due to the relative quality of instream habitat and riverscape connectivity in the Big Bend reach, an experimental population of threatened H. amarus was reintroduced in 2009 (Shiley and Lamberti 2010). In the years since, $H$. amarus eggs have been collected in drift samples (Roberson 2010) and adult individuals have been collected on at least 4 occasions (M. Bean, Texas Parks and Wildlife Department, personal communication). These anecdotal observations support our conclusions that maintaining a diversity of instream habitats coupled with dynamic flows likely allow for speciesspecific associations and persistence of imperiled fishes within the Big Bend reach of the Rio Grande.

\section{ACKNOWLEDGMEnTS}

We thank C.S. Williams, D.T. Runyan, B.M. Fordham, and M.G. Bean for assistance in the field. Sampling permits and river access were granted by Texas State University-San Marcos (IACUC 06-0620 802), the Texas Parks \& Wildlife Department (Permit SPR-0601-159; issued to THB, 1 Jun 2001-1 Jun 2007), Big Bend National Park (Permit BIBE-2005-SCI0071; issued to THB, 1 May 2005-30 Dec 2007), and Black Gap Wildlife Management Area (BG 06-01; issued to TCH, 1 Jan 200631 Dec 2006). We extend a special thanks to the late C. Hubbs for his assistance during early portions of this study and for his lifelong dedication to Texas fishes. We thank C.S. Williams and C.W. Hoagstrom for comments on earlier versions of this manuscript. This project was funded by the Texas Rivers Systems Institute at Texas State University-San Marcos and, in part, by Fred and Yetta Richan Aquatic Biology Scholarships awarded to TCH.

\section{Literature Cited}

Ahmadi-Nedushan, B., A. St-Hilaire, M. Bérubé, É Robichaud, N. Thiémonge, And B. Bobée. 2006. A review of statistical methods for the evaluation of aquatic habitat suitability for instream flow assessment. River Research and Applications 22: 503-523.

Anderson, A.A., C. Hubbs, K.O. Winemiller, and R.J. EDWARDS. 1995. Texas freshwater fish assemblages following three decades of environmental change. Southwestern Naturalist 40:314-321.

Bean, P.T., T.H. Bonner, And B.M. LitTrell. 2007. Spatial and temporal patterns in the fish assemblage of the Blanco River, Texas. Texas Journal of Science 59:179-200.

Bestgen, K.R., and S.P. Platania. 1990. Extirpation of Notropis simus simus (Cope) and Notropis orca Woolman (Pisces: Cyprinidae) from the Rio Grande in New Mexico; with notes on their life history. Occasional Papers of the Museum of Southwestern Biology, University of New Mexico 6:1-8.

1991. Status and conservation of the Rio Grande silvery minnow, Hybognathus amarus. Southwestern Naturalist 36:225-232.

BOND, N.R., AND P.S. LAKE. 2003. Characterizing fishhabitat associations in streams as the first step in ecological restoration. Austral Ecology 28:611-621.

Bray, J.R., AND J.T. CurTis. 1957. An ordination of the upland forest communities of southern Wisconsin. Ecological Monographs 27:325-349.

Bunn, S.E., And A.H. ARThington. 2002. Basic principles and ecological consequences of altered flow regimes for aquatic biodiversity. Environmental Management 30:492-507.

Calamusso, B., J.N. Rinne, and R.J. Edwards. 2005. Historic changes in the Rio Grande fish fauna: status, threats, and management of native species. Pages 205-223 in J.N. Rinne, R.M. Hughes, and B. Calamusso, editors, Historical changes in large river fish assemblages of the Americas, Symposium 45. American Fisheries Society, Bethesda, MD.

Clarke, K.R. 1993. Nonparametric multivariate analyses of changes in community structure. Australian Journal of Ecology 18:117-143.

Clarke, K.R., and R.H. Green. 1988. Statistical design and analysis for a 'biological effects' study. Marine Ecology Progress Series 46:213-226.

Collins, J.P., C. Young, J. Howell, And W.L. Minckley. 1981. Impact of flooding in a Sonoran Desert stream, including elimination of an endangered fish population (Poeciliopsis o. occidentalis, Poeciliidae). Southwestern Naturalist 26:415-423.

Cummins, K.W. 1962. An evaluation of some techniques for the collection and analysis of benthic samples with special emphasis on lotic waters. American Midland Naturalist 67:477-504.

DEAn, D.J., AND J.C. SchmidT. 2011. The role of feedback mechanisms in historic channel changes of the lower Rio Grande in the Big Bend region. Geomorphology 126:333-349.

Dudgeon, D., A.H. Arthington, M.O. Gessner, Z.I. KAWabata, D.J. Knowler, C. Leveque, R.J. Naiman, A.H. Prieur-Richard, D. Soto, M.L.J. Stiassny, AND C.A. SulLivan. 2006. Freshwater biodiversity: importance, threats, status and conservation challenges. Biological Reviews 81:163-182.

Dudley, R.K., AND S.P. Platania. 2007. Flow regulation and fragmentation imperil pelagic-spawning riverine fishes. Ecological Applications 17:2074-2086.

Durham, B.W., and G.R. WILdE. 2005. Relationship between hatch date and first-summer growth of five species of prairie-stream cyprinids. Environmental Biology of Fishes 72:45-54.

EDWards, R.J., AND S. Contreras-Balderas. 1991. Historical changes in the ichthyofauna of the lower Rio 
Grande (Río Bravo del Norte), Texas and Mexico. Southwestern Naturalist 36:201-212.

Edwards, R.J., G.P. Garrett, and E. Marsh-Matthews. 2002. Conservation and status of the fish communities inhabiting the Rio Conchos basin and middle Rio Grande, Mexico and U.S.A. Reviews in Fish Biology and Fisheries 12:119-132.

Farringer, R.T., III, A.A. ECHELLE, AND S.F. LEHTINEN. 1979. Reproductive cycle of the red shiner, Notropis lutrensis, in central Texas and south central Oklahoma. Transactions of the American Fisheries Society 108 271-276.

Gido, K.B., D.L. Propst, and M.C. Molles Jr. 1997. Spatial and temporal variation of fish communities in secondary channels of the San Juan River, New Mexico and Utah. Environmental Biology of Fishes 49 $417-434$.

Guégan, J.F., S. Lek, AND T. OberdorfF. 1998. Energy availability and habitat heterogeneity predict global riverine fish diversity. Nature 391:382-384.

Hallgren, E., M.W. Palmer, and P. Milberg. 1999 Data diving with cross-validation: an investigation of broad-scale gradients in Swedish weed communities. Journal of Ecology 87:1037-1051.

HarveY, B.C. 1987. Susceptibility of young-of-the-year fishes to downstream displacement by flooding. Transactions of the American Fisheries Society 116:851-855.

Helfman, G.S. 2007. Fish conservation: a guide to understanding and restoring global aquatic biodiversity and fishery resources. Island Press, Washington, DC.

Hoagstrom, C.W., J.E. Brooks, and S.R. Davenport 2008. Spatiotemporal population trends of Notropis simus pecosensis in relation to habitat conditions and the annual flow regime of the Pecos River, 1992 2005. Copeia 2008:5-15.

Holden, P.B. 1979. Ecology of riverine fishes in regulated stream systems with emphasis on the Colorado River Pages 54-74 in J.V. Ward and J.A. Stanford, editors, The ecology of regulated streams. Plenum Press, New York, NY.

Hubbs, C., R.J. Edwards, and G.P. Garrett. 2008. An annotated checklist of the freshwater fishes of Texas, with keys to identification of species. Texas Academy of Science; [cited 1 June 2009]. Available from: http:// www.texasacademyofscience.org/.

Hubbs, C., R.R. Miller, R.J. EdWards, K.W. Thompson, E. Marsh, G.P. Garkett, G.L. Powell, D.J. Morris, AND R.W. ZERr. 1977. Fishes inhabiting the Rio Grande, Texas and Mexico, between El Paso and the Pecos confluence. Pages 91-97 in R.R. Johnson and D.A. Jones, editors, Importance, preservation, and management of riparian habitat: a symposium. Technical Report Number 43, United States Department of Agriculture, Fort Collins, CO.

Hughes, R.M., J.N. Rinne, and B. Calamusso. 2005. Historical changes in large river fish assemblages of the Americas: a synthesis. Pages 603-612 in J.N. Rinne, R.M. Hughes, and B. Calamusso, editors, Historical changes in large river fish assemblages of the Americas, Symposium 45. American Fisheries Society, Bethesda, MD.

JelKs, H.L., S.J. Walsh, N.M. Burkhead, S. ContrerasBalderas, E. Diaz-Pardo, D.A. Hendrickson, J. Lyons, N.E. Mandrak, F. McCormick, J.S. NeLSON, ET AL. 2008. Conservation status of imperiled North American freshwater and diadromous fishes. Fisheries 33:372-407.
Jester, D.B. 1972. Life history, ecology, and management of river carpsucker, Carioides carpio (Rafinesque), with reference to Elephant Butte Lake. Research Report No. 243, New Mexico State University Agricultural Experiment Station, Las Cruces, NM.

Kim, T.W., J.B. Valdes, and J. Aparicio. 2002. Frequency and spatial characteristics of droughts in the Conchos River Basin, Mexico. Water International $27: 420-430$

Kinsolving, A.D., AND M.B. Bain. 1993. Fish assemblage recovery along a riverine disturbance gradient. Ecological Applications 3:531-544.

Krebs, C.J. 1999. Ecological methodology. 2nd edition. Addison-Welsey Educational Publishers, Menlo Park, CA.

LAKE, P.S., N. BOND, AND P. ReICH. 2007. Linking ecological theory with stream restoration. Freshwater Biology 52:597-615.

Matthews, W.J. 1986a. Fish faunal structure in an Ozark stream: stability, persistence and a catastrophic flood. Copeia 1986:388-397.

1986b. Geographic variation in thermal tolerance of widespread minnow Notropis lutrensis of the North American Mid-west. Journal of Fish Biology 28:407-417.

McMahon, T.E., A.V. Zale, and D.J. ORTh. 1996. Aquatic habitat measurements. Pages 83-120 in B.R. Murphy and D.W. Willis, editors, Fisheries techniques. 2nd edition. American Fisheries Society, Bethesda, MD.

Minckley, W.L., and G.K. Meffe. 1987. Differential selection by flooding in stream-fish communities of the arid American Southwest. Pages 93-104 in W.J. Matthews and D.C. Heins, editors, Community and evolutionary ecology of North American stream fishes. University of Oklahoma Press, Norman, OK.

Moring, J.B. 2002. Baseline assessment of instream and riparian-zone biological resources on the Rio Grande in and near Big Bend National Park, Texas. WaterResources Investigations Report 02-4106. United States Geological Survey, Austin, TX.

ØKLAND, R.H. 1999. On the variation explained by ordination and constrained ordination axes. Journal of Vegetation Science 10:131-136.

Owens, J.E., AND E.D. Niemeyer. 2006. Analysis of chemical contamination within a canal in a Mexican border colonia. Environmental Pollution 140:506-515.

Perkin, J.S., And T.H. Bonner. 2011. Long-term changes in flow regime and fish assemblage composition in the Guadalupe and San Marcos rivers of Texas. River Research and Applications 27:566-579.

Platania, S.P., and C.S. Altenbach. 1998. Reproductive strategies and egg types of seven Rio Grande Basin cyprinids. Copeia 1998:559-569.

Poff, N.L., J.D. Allan, M.B. Bain, J.R. Karr, K.L. PresteGaARD, D.B. Richter, R.E. SParks, and J.C. StromBERG. 1997. The natural flow regime: a paradigm for river conservation and restoration. Bioscience 47: $769-784$

POFF, N.L., AND J.V. WARD. 1989. Implications of streamflow variability and predictability for lotic community structure: a regional analysis of streamflow patterns. Canadian Journal of Fisheries and Aquatic Sciences 46:1805-1818.

Propst, D.L., AND K.B. Gido. 2004. Responses of native and nonnative fishes to natural flow regime mimicry in the San Juan River. Transactions of the American Fisheries Society 133:922-931.

Roberson, A. 2010. A little fish in Big Bend: Rio Grande silvery minnow showing signs of reproduction in 
Texas. Eddies, Reflections on Fish Conservation 3(1):20-23. U.S. Fish and Wildlife Service, Albuquerque, NM.

Ross, S.T. 2001. The inland fishes of Mississippi. University Press of Mississippi, Jackson, MS.

Sansom, A. 2008. Water in Texas: an introduction. University of Texas Press, Austin, TX.

SchmidT, J.C., B.L. Everitt, and G.A. Richard. 2003. Hydrology and geomorphology of the Rio Grande and implications for river restoration. Pages 25-42 in G.P. Garrett and N.L. Allan, editors, Aquatic fauna of the northern Chihuahuan Desert. University Special Publications Number 46, Museum of Texas Tech, Lubbock, TX.

Schultz, A.A., O.E. Maughan, S.A. Bonar, and W.J. MatTER. 2003. Effects of flooding on abundance of native and nonnative fishes downstream from a small impoundment. North American Journal of Fisheries Management 23:503-511.

ScotT, M.C., AND G.S. Helfman. 2001. Native invasions, homogenization, and the mismeasure of integrity of fish assemblages. Fisheries 26(11):6-15.

Shiley, P.D., AND G.A. LAMBERTI. 2010. Assisted colonization under the U.S. Endangered Species Act. Conservation Letters 3:45-52

Simonson, T.D., J. Lyons, AND P.D. Kanehl. 1994. Quantifying fish habitat in streams: transect spacing, sample size, and a proposed framework. North American Journal of Fisheries Management 14:607-615.

Small, M.F., T.H. BonNER, AND J.T. Baccus. 2009. Hydrologic alteration of the lower Rio Grande terminus: a quantitative assessment. River Research and Applications 25:241-252.

Sturges, H.A. 1926. The choice of a class interval. Journal of the American Statistical Association 21:65-66.
TER BRAAK, C.J.F. 1986. Canonical correspondence analysis: a new eigenvector technique for multivariate direct gradient analysis. Ecology 67:1167-1179.

[USGS] United States Geological Survey. 2004. Biomonitoring of environmental status and trends (BEST) program: environmental contaminants and their effects on fish in the Rio Grande Basin. Scientific Investigations Report 2004-5108. United States Geological Survey, Austin, TX.

Valdez, R.A., T.L. Hoffnagle, C.C. McIvor, T. McKinNEY, AND W. LeIBRIED. 2001. Effects of a test flood on fishes of the Colorado River in Grand Canyon, Arizona. Ecological Applications 11:686-700.

VelLEND, M. 2010. Conceptual synthesis in community ecology. Quarterly Review of Biology 85:183-206.

WARD, J.V., AND J.A. STANFORD. 1979. The ecology of regulated streams. Plenum Press, New York, NY

Williams, C.S., AND T.H. BonNER. 2006. Habitat associations, life history and diet of the Sabine shiner Notropis sabinae in an east Texas drainage. American Midland Naturalist 155:84-102.

Winston, M.R., C.M. TAYLOR, AND J. PigG. 1991. Upstream extirpation of four minnow species due to damming of a prairie stream. Transactions of the American Fisheries Society 120:98-105.

ZaValeta, E. 2000. Valuing ecosystem services lost to Tamarix invasion in the United States. Pages 261-300 in H.A. Mooney and R.J. Hobbs, editors, Invasive species in a changing world. Island Press, Washington, DC.

Received 3 August 2011 Accepted 10 November 2011 